\title{
POLICE PROCEDURE FOR HANDLING ORDERS AND REQUESTS ISSUED BY THE COMPETENT AUTHORITIES
}

Review Paper

\begin{tabular}{|l|l|l|}
\hline DOI 10.7251/ZBKEN1901011M & COBISS.RS-ID 8273944 & UDK 351.74/.76:343.14/.15 \\
\hline
\end{tabular}

\author{
Dragan Milidragović ${ }^{1}$ \\ Ministry of the Interior of the Republic of Serbia
}

\section{Dane Subošić}

University of Criminal Investigation and Police Studies, Belgrade, Serbia

Nenad Milić

University of Criminal Investigation and Police Studies, Belgrade, Serbia

\begin{abstract}
In addition to the police duties set forth in Article 30(3) of the Law on Police (hereinafter referred to as Law), the police perform other duties and tasks established by law. A number of these duties pertain to the provision of assistance to other government bodies, primarily to the courts and prosecutors' offices in carrying out tasks within their scope of work, which consists of handling their orders and requests. To establish the amount of time police officers in the security sector spend on handling orders and requests, this paper presents sections of four surveys dealing with the engagement of police officers in performing these duties. The survey findings presented indicate that the police of the Republic of Serbia spend a considerable amount of working time on handling orders and requests and performing other tasks that are not directly related to the prevention and repression of crime. The fact that police officers are overwhelmed with an increasing number of orders and requests is, in addition to the survey findings presented, confirmed by the statistics of the Ministry of the Interior of the Republic of Serbia in the period 2010-2013, which is also presented in this paper. According to the statistical data, judicial authorities annually send over 101.000 requests for serving summons, about 435.000 orders for bringing in persons, and more than 100.000 requests for the verification of residence addresses, of which $75 \%$ pertains to field verification of residence addresses. The problem of spending most of the working time on handling orders and requests has been present for more than ten years in policing in the security sector. In resolving this problem, we propose to examine experience from other countries whose law enforcement agencies have entrusted some of their work to other government bodies or the private security sector.
\end{abstract}

Keywords: police, orders, requests, statistical data, working time

\footnotetext{
${ }^{1}$ Corresponding author: Dragan Milidragovic, Ministry of the Interior of the Republic of Serbia. E-mail: dragan.milidragovic@mup.gov.rs.
} 


\section{INTRODUCTION}

In addition to the police duties set forth in Article 30(3) of this Law, ${ }^{2}$ the police also perform other duties and tasks specified by law and by-laws. A number of these police duties and tasks pertain to the provision of assistance to other government bodies, competent courts and prosecutors' offices (hereinafter: assistance to the relevant authority) in carrying out tasks within their scope of work.

Assistance to relevant authorities should be distinguished from police assistance in the enforcements of out-of-court settlement procedures (hereinafter: police assistance). ${ }^{3}$ The police render assistance to government bodies, or those with legal authority, during the enforcement of their duties when there is reasonable expectation for their assistance.

The fundamental differences between these two types of assistance is the time when it is rendered. Police assistance is rendered after the proceedings has been concluded by the relevant authority, when, after the final judgment, a decision on the execution have been reached and when the executive bodies have attempted to execute it. Unlike police assistance, assistance to the relevant authority is provided in the course of the proceedings.

The legal basis for the provision of police assistance is contained in Article 53 of this Law, while the legal basis for the provision of assistance to the relevant authority is provided for in Article 30, paragraph 3, item 12 of this Law.

Paragraph 3 of Article 30 contains police duties, while Item 12 of this Article stipulates that police duties also relate to the performance of other duties and tasks established by law and by-laws deriving from the law.

According to Slobodan Miletić, other tasks established by law and bylaws are deemed police duties if they are established as such by laws and other regulations. If this is not the case, it may be concluded that they are deemed police duties only if they meet the same criteria as other duties do. These criteria relate to: (1) nature, (2) character, and (3) the manner of performing police duties. By nature, and character, police duties refer to security and operationalduties, while (special) police powers are usually exercised in the performance of these duties. By the manner of performance, police duties are characterized by the specificity and immediacy of police procedure, the provision of security protection at the incident scene (police interventions on the spot). Unlike police duties, the aim of performing other internal affairs is not the direct protection of security - other internal affairs are, by nature and character, predominantly administrative and non-administrative affairs of the administration. Regarding the manner of performance, they are not characterized by the specificity and

\footnotetext{
${ }^{2}$ Official Gazette of the RoS, Nos. 6/2016, 24/2018 and 87/2018. See Article 30 of the Law on Police.

${ }^{3}$ For more details on the manner of rendering police assistance, see Articles 53-56 of the Law on Police.
} 
immediacy of police procedure and may be performed by other agencies other than the police (Miletić, 2009: 45).

Police duties pertaining to uncovering and apprehending perpetrators of criminal offenses and misdemeanors as well as other persons wanted by the authorities and bringing them before the competent authorities, ensuring and analyzing evidence, conducting forensic analysis using modern forensic methods and records, require the exercise of police powers, for example, questioning suspects, collecting information from citizens, communications surveillance, forensic expertise, and the like.

According to the criteria listed by Miletić, solving crimes may be regarded as security and operational activities with police officers exercising their authority in the performance of these duties. In the case of the third criterion stated by Miletić, we believe that the concreteness and immediacy of the on-site procedure are not essential criteria for a certain duty to be regarded as a police duty. In the process of detecting and solving crimes, certain police powers are not exercised on the spot, (e.g., the questioning of suspects, communications surveillance, and the like). The same is true when handling orders and requests. Handling these legal documents requires the exercise of police authority, such as identity checks, conveying/bringing in persons, and sometimes the use of coercive means. Based on this explanation, we may say that the police duties are those duties whose performance requires the exercise of police powers and which are in the direct or indirect function of security.

More precisely, the obligations of the police in handling orders and requests are contained in the Misdemeanor $\mathrm{Law}^{4}$, the Criminal Procedure Code $^{5}$, the Law on Execution of Criminal Sanctions ${ }^{6}$, Civil Procedure Law ${ }^{7}$, and the Law on General Administrative Procedures.

In the literature as well as in the positive regulations, the notions of order and request have not been specified. In the Dictionary of the Serbian Language, the word naredba [Engl. order] is defined as: a) a legal act issued by the authority determining the obligations of the natural and legal persons over whom they are competent, b) in general, the request of one who has the power, military force and the like, which determines something as an obligation or command (Vujanić et al., 2007: 788).

Taking into account these meanings, the order can be defined as a legal act issued by the authorities, by which they order the competent authorities to execute certain actions for the purpose of concluding their proceedings. The

${ }^{4}$ Official Gazette of the RoS, Nos. 65/2013, 13/2016 и 98/2016-judgment by the Administrative Court.

${ }^{5}$ Official Gazette of the RoS, Nos. 72/2011, 101/2011, 121/2012, 32/2013, 45/2013, 55/2014 .

${ }^{6}$ Official Gazette of the RoS, No. 55/2014.

${ }^{7}$ Official Gazette of the RoS, Nos. 72/2011, 49/2013-judgement of the Administrative Court, 55/2014 and 87/2018.

${ }^{8}$ Official Gazette of the RoS, No. 18/2016. 
competent prosecutor's offices and courts may issue orders for the purpose of bringing in the defendant for the purpose of questioning him, if the defendant properly summoned does not appear after he or she has been served a summon, and his absence is not justified, or if the summon to attend the hearing could not be properly served. The grounds to act upon the orders of the competent prosecutor's offices and courts for bringing the defendant to the hearing represent the statutory solutions contained in the $\mathrm{CPC}^{9}$, while the grounds for bringing the defendant to the misdemeanor court are the solutions contained in the ML. ${ }^{10}$ In addition to orders for bringing in persons in the course of the proceedings, the competent courts also issue orders for bringing in sentenced ${ }^{11}$ or convicted persons. ${ }^{12}$

In the Dictionary of the Serbian Language, the word zamolnica [Engl. request] is defined as a written request/application from a court to another court to provide legal or technical assistance (Vujanić et al., 2007: 403). Starting from this definition, we can define zamolnicu as an application/request by a government authority addressed to another government body to provide legal or technical assistance, necessary for the initiation or conclusion of certain proceedings. The requests from government bodies addressed to the police primarily pertain to serving various decisions, judgments, summons, verifying residence addresses, and the like.

In police practice, orders and requests are handled by the general jurisdiction police and the execution of them represents secondary or servicerelated work. The number of orders and requests the police receive today is increasing and the substantial use of certain resources and time is required to execute them.

\section{SURVEY RESULTS ON POLICE PROCEDURE FOR HANDLING ORDERS AND REQUESTS}

This section presents findings of three surveys conducted on the organization and policing in the area of the prevention and repression of crime - two surveys were conducted using a survey sheet, while the third survey was conducted by means of interviews. The study conducted by Ivan Đorović is also presented, including the observations of some commentators pointing to the police being overloaded with orders, requests, and other administrative work.

In order to comprehend the engagement of police officers in the security sector in performing police duties, in 2011, a survey was carried in two largest

\footnotetext{
9 See Articles 195 and 196 of the CPC.

${ }^{10}$ See Articles 188 and 189 of the ML.

${ }^{11}$ See Articles 217-220 of the LECS.

${ }^{12}$ See Articles $53-58$ of the LECS.
} 
police departments within the Ministry of the Interior of the Republic of Serbia - the City of Belgrade Police Department and the City of Novi Sad Police Department.

The survey involved 415 officers employed in the general jurisdiction police, 260 police officers working on the territory under the jurisdiction of the Police Department in Belgrade (62\% of the respondents), and 155 police officers working on the territory under the jurisdiction of the Police Department in Novi Sad (38\% of the respondents).

Through the survey, the respondents were asked 20 questions regarding the procedure for handling orders and requests issued by the competent authorities, the preventive and repressive policing in the security sector, including the motivation of police officers.

The investigation encompassed the following police outposts in the Novi Sad Police Department: Stari grad, Detelinara, Klisa, Petrovaradin, Liman, and Futog, and three police stations within the City of Belgrade Police Department: Zemun, Stari grad, and Novi Beograd. ${ }^{13}$

The police officers interviewed were grouped into four groups according to their work experience in the police force. The first group consisted of the respondents with 0 to 3 years of work experience, the second group with 3 to 5 years of work experience, the third 5 to 10 years of work experience, while the fourth group consisted of the respondents with over 10 years of work experience. Of the 415 police officers surveyed, the largest number of them had over 10 years of work experience, accounting for $38.8 \%$ of the total sample, followed by police officers with working experience of 5 to 10 years accounting for $30.8 \%$, then police officers with 3 to 5 years of work experience accounting for $13.5 \%$, and finally police officers with 0 to 3 years of work experience accounting for $16.9 \%$ (Table 1).

Table 1 - Distribution of respondents by years of work experience

\begin{tabular}{|l|l|l|}
\hline $\begin{array}{l}\text { Years of work experience in the } \\
\text { police force }\end{array}$ & $\begin{array}{l}\text { Number of } \\
\text { respondents }\end{array}$ & $\begin{array}{l}\text { Number of respondents in } \\
\text { terms of percentages }\end{array}$ \\
\hline From 0 to 3 years & 70 & $16.9 \%$ \\
\hline From 3 to 5 years & 56 & $13.5 \%$ \\
\hline From 5 to 10 years & 128 & $30.8 \%$ \\
\hline Over 10 years & 161 & $38.8 \%$ \\
\hline Total & 415 & $100 \%$ \\
\hline
\end{tabular}

${ }^{13}$ For more details on this survey, see: Milidragović, 2016: 42-69. 
The survey encompassed the police officers who were assigned to the following job positions in police outposts: police officers, sector chiefs, deputies of sector chiefs, shift chiefs (leaders), and assistant shift chiefs (leaders). The largest number of the respondents were police officers who accounted for $73.3 \%$ (or 304 respondents), shift chiefs (leaders) and assistant shift chiefs accounting for $13.5 \%$ (or 56 respondents), while the number of deputy sector chiefs accounted for $13.3 \%$ (or 55 respondents) (Table 2 ).

The majority of respondents, or $70 \%$, had more than five years of work experience in the police force. The fact that more than two thirds of the respondents have significant work experience in the police force ( 5 years or over 5 years) gives a special value to the survey findings obtained ( $31 \%$ of the respondents have 5 to 10 years of service, while $39 \%$ of the respondents have over 10 years of service).

Table 2 - Distribution of respondents by job position

\begin{tabular}{|l|l|l|}
\hline Job position in the police precinct & $\begin{array}{l}\text { Number of } \\
\text { respondents }\end{array}$ & $\begin{array}{l}\text { Results in terms of } \\
\text { percentages }\end{array}$ \\
\hline Police officer & 304 & $73.3 \%$ \\
\hline $\begin{array}{l}\text { Sector chief and deputy of } \\
\text { sector chief }\end{array}$ & 55 & $13.3 \%$ \\
\hline $\begin{array}{l}\text { Shift chief (leader) and } \\
\text { assistant sector chief (leader) }\end{array}$ & 56 & $13.5 \%$ \\
\hline Total & 415 & $100 \%$ \\
\hline
\end{tabular}

Of the total of 20 survey questions, the respondents were asked to provide answers to two questions about the procedure for handling issued orders and requests. Prior to responding to these two questions, the respondents were given the opportunity to declare themselves, by writing numbers 1 to 5 preceding police duties offered (securing public gatherings, suppressing crime - uncovering crimes and finding the perpetrators and persons wanted by the police; maintaining order and peace, handling orders and requests, and preventive visits to the security sector), about police tasks that take up most of the time during working time. Number 1 signified a duty requiring a high level

14 of engagement, while number 5 referred to a police duty requiring the lowest level of engagement during a regular shift. 


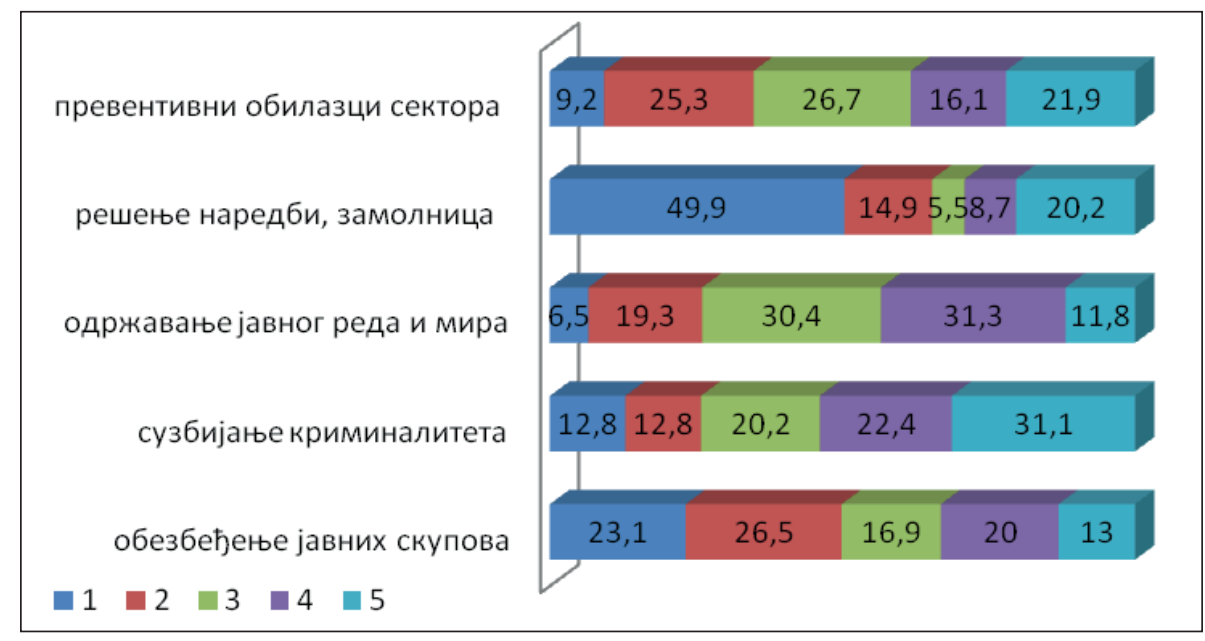

Figure 1 - Distribution of police officer working hours ${ }^{14}$

Of all the aforementioned duties performed on a daily basis, $49.9 \%$ of the respondents stated that they were engaged in handling issued orders and requests most of the time during their regular shift. With this distribution of forces and resources, the police become less engaged in performing priority police duties, primarily the prevention and repression of crime and the maintenance of public order and tranquility. An increasing number of orders and requests from competent courts and other government bodies place the police in the position of a courier service, which engages its forces and resources to perform these duties (Figure 1).

The fact that the lack of resources is equally bad for the police organization as well as their irrational use is often neglected. In this regard, the optimization of the engagement of available resources implies an analysis of the content of the work of police officers in the structure of their working time. For example, police officers spend a considerable amount of working time on performing duties which are not related to crime and the maintenance of public order and tranquility. Duties such as the conduct of background checks on job candidates, checks regarding firearms, handling requests from other government bodies (e.g., the verification of residence addresses) push preventive actions (e.g., visits to catering facilities where crimes and violations often occur, the creation and improvement of partnership relations with the members of a community, and so on) or detecting and solving crimes pushed into the background..$^{15}$

14 Translator's note: preventive patrolling around the sector, handling orders and requests, maintaining public order and tranquility, crime suppression, securing public events.

${ }^{15}$ The studies conducted so far in the United States demonstarte that activities related to combating crime and the forced enforcement of the law account for only $20 \%$ to $30 \%$ of the overall police work. Police officers spend $70 \%-80 \%$ of working time on the so-called. "social service work", rather than on the activities pertaining to combating crime (Banton, 1964: 6-7). 
In order to see what amount of time police officer spend on performing such duties and tasks, the police officers were asked to indicate how much time they spend during the service (shift) on handling orders, requests, serving judgments and summons, verifying addresses and handling other requests from courts. Most of them (46\%) responded that they spend more than 3 hours of their working time on performing these duties. Also, one-fifth of the respondents (20\%) spend 1 to 2 hours on perform these duties during their shift, while $22 \%$ of the respondents spend 2 to 3 hours on performing these duties. Almost one in ten respondents spend up to 1 hour of their working time on these tasks (Table 3).

Table 3. Results obtained from the question about the amount of time spent on handling orders and requests

\begin{tabular}{|c|c|c|}
\hline Response options & Number of respondents & Results in terms of percentages \\
\hline Up to 1 hour & 50 & $12 \%$ \\
\hline 1 to 2 hours & 82 & $20 \%$ \\
\hline 2 to 3 hours & 91 & $22 \%$ \\
\hline Over 3 hours & 192 & $46 \%$ \\
\hline Total & 415 & $100 \%$ \\
\hline
\end{tabular}

Bearing in mind the above issues, we may conclude that the performance of these duties represents a significant burden to police officers in urban areas, and, therefore, some other way to perform these duties has to be found so that it does not threaten the regular functioning of the police organization and the security within a certain territory. This view is supported by the results of the responses obtained from the question about the jurisdiction over handling orders and requests. The majority of the police officers ( $76 \%$ of the respondents) believe that the police should not perform these tasks (handling orders and requests), (Table 4 ). 
Table 4. Results obtained from the question about the possible transfer of jurisdiction over handling orders and requests

$\begin{aligned} & \text { Do you think that handling issued orders and requests should be under the } \\
& \text { jurisdiction of a special organizational unit within the court (for example, } \\
& \text { judicial police or similar)? }\end{aligned}$
\begin{tabular}{|l|l|l|} 
Response options & $\begin{array}{l}\text { Number of } \\
\text { respondents }\end{array}$ & $\begin{array}{l}\text { Results in terms } \\
\text { of percentages }\end{array}$ \\
\hline The police should not perform these duties & 316 & $76 \%$ \\
\hline The police should perform these duties & 54 & $13 \%$ \\
\hline No opinion & 45 & $11 \%$ \\
\hline Total & 415 & $100 \%$ \\
\hline
\end{tabular}

It is necessary to seek to establish other services within the judicial bodies (e.g., the judicial police) to perform a number of duties currently performed by police officers (residence address verification, serving court judgments and decisions, assistance, and so on), or consider the possibility of engaging an auxiliary police force to perform these tasks in those police outposts/stations where these duties endanger the normal functioning of a police organization.

In analyzing the problems of policing in the local area in 2008, Radoslav Plachkov concluded that police officers spend most of their working time conducting background checks on job candidates and for firearms, assistance, handling requests from other government bodies often related to verifying residence addresses and orders issued by misdemeanor bodies to convey a person for failure to pay a mandatory fine, amounting to several thousands in one city sector on a yearly bases, and the like (Plachkov, 2008: 136-137).

In 2004, Kešetović reached the same conclusion. In analyzing policing, Kešetović concluded that an increasing number of obligations imposed on police officers (leaders of the security sectors and the police in the security sector) makes it difficult for them to carry out their main task - the prevention of, and combating crime. Based on the analysis of the tasks they perform, Kešetović concluded that police officers spend $60 \%$ to $80 \%$ of their working time on performing tasks that have nothing to do with combating crime (Kešetović, 2004: 526).

Based on the survey conducted and the analysis of the manner police officers spend their working time in the police outposts within the headquarters of the police department in Kragujevac, Đorović concludes that 30\% of working time could be "freed" in this way and used for other purposes, such as the greater involvement of police officers in the content of the community policing concept (Đorović, 2011: 232).

In the period from March to June, 2014, an interview was conducted with the leaders of organizational units in charge of organizing and monitoring 
community policing. Also, during the same period, a survey was conducted in all 27 police departments on the organization and work of the general jurisdiction police in the prevention and repression of crime, as well as on certain factors impeding their work. ${ }^{16}$

The interview was conducted with the chiefs of the Department for Organization, Prevention, Training and Community Policing in Novi Sad, Kragujevac, Niš, in the regional police departments, then with the Chief of the Department for Prevention and Community Policing within the City of Belgrade Police Department, and with the Chief of the Department for Prevention and Community Policing in the Police Department within the Police Directorate Headquarters.

The respondents were asked a total of 15 questions about the representation of community policing in the general jurisdiction police and the effects and problems in policing. In responding to the question about the representation of preventive work in the security sector, all the respondents emphasized that preventive work was under-represented, primarily due to an increasing number of tasks related to orders and requests, followed by a small number of police officers in police outposts, the inappropriate organizational structures of the police, the lack of knowledge on prevention and policing, as well as the focus which has been placed on handling daily or short-term problems.

A total of 359 police officers were interviewed through the survey questions. Leaders within the Police Department (chiefs, deputy chiefs, department leaders), in the police stations/outposts (commanders, deputy and assistant commanders) and ranked officers in the Police Department participated in the survey.

More than half of the police officers interviewed, 188 out of 359 (or $52.4 \%$ ), were leaders within police stations/outposts (commander, deputy and assistant commander), at least 33 (or 9.2\%) of the respondents were heads/ leaders within the Police Department (chief, deputy chief, department head). There were 138 (or 38.4\%) ranked officers in the Police Department.

In responding to the question about the representation of preventive activities in daily policing, the largest number of respondents (310 of 359) said that preventive activities are not represented. The respondents were offered the opportunity to express themselves regarding the factors that, in their opinion, affect the under-representation of prevention in daily policing. The largest number of respondents, 285 out of 310 (or 79.4\%), believe that preventive activities are not represented in the daily work of the police due to the overload of the police with tasks such as serving requests and handling orders issued by the competent bodies.

Based on the survey findings and the observations of the mentioned scholars, the question arises as to whether such an organization of police work can successfully meet the citizens' expectations who finance the police

16 For more details, see: Милидраговић, 2016. 
through taxes and whose interests it should serve. In order to control crime, the police must enter the pretext of crime to see and act on the causes and conditions leading to its occurrence. However, as these causes and conditions are, as a rule, out of the reach of police action, there is also a need for the mobilization of other entities in the society in order to jointly counter crime. The moment it became clear that the police alone could not counter crime, primarily those factors affecting the quality of life of citizens, it became clear that the partnership with the community and other stakeholders became an important element in the exercise of police functions. ${ }^{17}$

If we consider the fact that many problems requiring police action arise and manifest themselves in the local community, then establishing and maintaining partnerships with the community is a prerequisite for the efficient operation of a police organization This is the reason why it is necessary to create organizational preconditions in police work that will enable that. Therefore, the implementation of the concepts of community policing and problem-oriented ${ }^{18}$ work should be restored, which have been largely neglected in our country, and whose significance in modern police practice has long been confirmed.

The survey findings presented demonstrate that the Serbian police are largely engaged in "courier" and other activities that are not related to the prevention and repression of crime. This type of the organization of police work requires changes in the organization of work, the establishment of partnership relations with the community, and the implementation of the concept of community policing.

\section{STATISTICAL INDICATORS FOR POLICE PROCEDURE FOR HANDLING ORDERS AND REQUESTS}

An increasing number of orders and requests served to increase work loads of police officers, which, in addition to the survey findings presented, has been confirmed by the statistics of the Ministry of the Interior of the Republic of Serbia in the period from 2010 to 2013.

\footnotetext{
${ }^{17}$ Community policing places an emphasis on prevention as a primary task of the police. It is based on the strategy of communication, cooperation and police reliance on citizens, while at the same time maximizing the restriction of the use of force and replacing it with assertive and partnership action (Bayley, 1990: 85). The concept of community policing involves the association of citizens and police in the fight against crime, that is, the performance of police affairs with the partnership of the police and community in order to reduce crime and increase security in the local community (Champion, 2003: 2).

${ }^{18}$ Incidents, which are a core part of policing (interventions), are only the symptoms (consequences) of the problem and will continue to manifest themselves as long as there are causes and conditions that generate them. Therefore, within a problem-oriented approach, police action does not end with the "resolution" of incidents (e.g., filing criminal or misdemeanor charges against the perpetrator), but continues with the aim of identifying the hidden causes and conditions leading to their occurrence (Milić, 2012: 125).
} 
According to the 2010 records of the Ministry of the Interior of the Republic of Serbia, there has been an increase in the number of requests from competent courts and prosecutors' offices to render them the necessary assistance in criminal and misdemeanor proceedings. Compared to 2010, the number of requests to serve a summon during the misdemeanor proceedings increased by $42 \%$ in 2013 , while the number of requests to serve a summon during the criminal proceedings in the same period increased by $55.2 \%$.

In the period from 2010 to 2013, police officers served 3,705 summons issued by misdemeanor courts and 4,319 summons from the prosecutors' offices and courts in charge of conducting criminal proceedings on a monthly basis. In the same period, the general jurisdiction police served more than $80 \%$ of the summons sent by misdemeanor courts and about $95 \%$ of the summons sent by the prosecutors' offices and courts in charge of conducting the criminal proceedings. During the studied period, the largest number of requests to be served were reported in the area of the City of Belgrade Police Department (approximately 1,700 requests received on a monthly basis), and the least number of summons was reported in the area of the Police Department in Prijepolje ( 32 summons on a monthly basis).

In the same period, the police received, on average, 27,909 orders issued by misdemeanor courts on a monthly basis, of which the police executed approximately 21,376 orders on a monthly basis. In contrast to this, the number of orders received from the courts in charge of conducting criminal proceedings was much smaller, and, on average, it amounted to 8.376 orders on a monthly basis, of which police officers executed, on average, 6,994 orders. During the studied period, the Serbian police received, on average, 8,334 requests to verify residence addresses, of which police officers executed, on average, 6,780 requests on a monthly basis.

In addition to the requests from competent courts and other government bodies to handle orders and requests, members of the general jurisdiction police also handle requests from other organizational units (traffic police, criminal police, and other units) regarding the serving of decisions on the sentence and statements on the imposed protective measures and security measures, requests to seize the passport, conducting security screening for citizenship application, background checks on job applicants, as well as submitted applications to keep and carry a weapon.

During the studied period, members of the general jurisdiction police conducted 2,542 security/background checks (application for citizenship, admission to employment with the Ministry of the Interior, and background checks for a weapon) on a monthly basis, of which they executed, on average, 258 orders to seize the passport.

Handling requests issued by the competent courts is significant and seems to be a specific duty within the scope of work of the general jurisdiction police, because without the proper serving of court summons or 
finding and apprehending the defendant, it is not possible to conclude the criminal proceedings. Based on the content of the request (serving summons, judgements, executing orders, and so on.), it may be concluded that the general jurisdiction police were engaged in all phases of the misdemeanor and criminal proceedings, which is illustrated by the fact that the judicial bodies annually delivered approximately 101,000 requests to serve summons and approximately 435,000 orders to convey persons, as well as over 100,000 requests to verify residence addresses, of which $75 \%$ pertains to field verification of residence addresses.

A large number of requests to the general jurisdiction police are also sent by other organizational units within the Ministry of the Interior. Members of the general jurisdiction police annually act, on average, in 3,925 cases upon the order to seize the passport and undertake 30,000 security screening for citizenship applications for, background checks on job applicants, and background checks pertaining to weapons. At the request of the traffic police, members of the general jurisdiction police serve about 71,000 decisions and almost 30,000 statements on imposed protective measures and security measures.

The survey results presented and the statistical data of the Ministry of the Interior of the Republic of Serbia on police procedure for handling issued orders and requests demonstrate that police officers are overloaded with these duties on a daily basis, pushing the tasks of prevention and repression of crime into the background.

\section{CONCLUSION}

The general jurisdiction police today, as well as several years back, spend a large amount of the available working time, forces and resources on handling requests issued by the competent prosecutor's offices, courts, and other government bodies and organizational units within the Ministry of the Interior.

In addition to the large number of orders and requests delivered, normative and practical problems have been identified in practice, making police officers' work more difficult. Police procedure for handling orders and requests indicates an overwhelming administration, starting from the receipt of requests, followed by making entries into police registers, verifying the justification and accuracy of data, organizing work, handling requests in the security sector, making reports on actions taken, responding to submitted requests, work control, and the like.

Police procedure for handling orders and requests is not prescribed the Law or any by-laws whatsoever. The Misdemeanor Law, Criminal Procedure Code, Law on General Administrative Procedure, and Law on the Execution of Criminal Sanctions only state the obligation of the police to provide 
the necessary assistance for the performance of duties that fall under the jurisdiction of prosecutors' offices, courts, and other bodies.

Prior to the enactment of the current Law on Police, in practice, the problem of fictitiously registered persons at specific addresses was particularly evident, as well as the problem of finding these persons, because they seek to avoid or hinder the execution of orders and avoid being served summons, decisions, and similar documents in various ways, which is why the police often act regarding the same person. ${ }^{19}$

In practice, it has been noted that the competent courts send a large number of orders and requests to the territorially competent police department to be handled within tight deadlines, which is why sometimes additional forces and resources are engaged at the same time, only for the performance of these tasks.

In addition to the above mentioned problems, subsequent problems are present in practice as well: upon the request sent, the judicial authorities do not provide information that an attempt to serve a summon has been made through the relevant courier services; requests to serve a summon contain only the name and surname of the person and no other data is provided, which makes it difficult for police officers to find that person; the Misdemeanor Law allows the person being conveyed to the court to pay a fine in several installments and, in the event that a person does not pay the installments properly, the court issues an order to convey that person again, consequently, some persons have been conveyed several times; the working time of the acting judges is exclusively in the morning, which sometimes makes it difficult for police officers to find a person; in some police departments, the remoteness of the local competent courts represents a problem as well. ${ }^{20}$

In resolving these problems, normative and practical mechanisms should be undertaken. The Law and by-laws should precisely regulate the obligation and the manner in which police officers handle orders and requests. Within practical measures, the possibility of introducing, in cooperation with the judicial bodies, an electronic information system for keeping various records should be taken into consideration.

Finally, experience from other countries whose police have entrusted some of their affairs to other government bodies or the private security sector should also be considered.

${ }^{19}$ It has been noted that the persons for whom a warrant of apprehension has been issued by the competent court, find out the date of the main trial from their lawyers or otherwise, and if it is not in their interest to appear in court on the date stipulated, they leave the house and go outside the city or visit a doctor on that day. Under the new Law on Police, the police may issue a wanted notice for a person for whom the misdemeanor court has issued a general order of apprehension (Article 59 , paragraph 4, item 2 of the Law).

${ }^{20}$ This problem arose following the reform of the judiciary in 2010 , when a new network of courts was established. 
In the Republika Srpska, the Federation of Bosnia and Herzegovina and the Brcko District, the judicial police was established under the Law on Judicial Police. $^{21}$

The judicial police in the Republika Srpska is competent to assist in the work of the Supreme Court, the Higher Commercial Court, district courts, basic courts, and district commercial courts. The judicial police of the Republika Srpska, within its competence, performs tasks related to information security, bringing in witnesses and expert witnesses by force, forcibly bringing in suspects, accused and convicted persons, the transportation of persons to penal institutions, the enforcement of court decisions, securing courts and prosecution facilities, securing judges and other court officials, the maintenance of order in the courtroom and other court premises during a trial.

In addition to handling orders and requests issued by competent prosecutors' offices and courts, the Serbian police perform other tasks which, in Bosnia and Herzegovina, fall under the jurisdiction of the judicial police, such as securing persons during the investigative hearing conducted by the investigative judge, who are brought after the detention period has expired, the transportation of persons against whom a detention order is issued by the investigative judge to penal and correctional institutions where the detention is carried out, the transportation of persons found on the basis of a wanted notice to the competent court authorizing the search. ${ }^{22}$

By establishing the judicial police within the territory of the Republic of Serbia, the general jurisdiction police would be relieved of a portion of the "courier" affairs. Working time and resources spent on performing tasks at the request of the prosecution and the court would focus on primary police affairs, the prevention and repression of crime, which would reflect on the safety of citizens and their property.

\footnotetext{
${ }^{21}$ For more details on the organization and work of judicial police in Bosnia and Herzegovina, see: https://sudpol-fbih.pravosudje.ba/, https://ossud-brckodistriktbih.pravosudje.ba/vstv/faces/kategorijevijesti.jsp?ins=90\&modul=7254 \&kat $=7285 \&$ kolona $=7269$, https://sudpol-rs.pravosudje.ba/. Retrieved on January 25, 2019.

${ }^{22}$ For example, if a person is found by police officers in the city of Subotica based on the order of apprehension issued by the High Court in Leskovac, they are obliged to bring the person to the court premises in Leskovac. In the event that a judicial police was established in the Republic of Serbia, the person found on a wanted notice would be handed over to the nearest judicial police unit which would then bring the person to the court in Leskovac.
} 


\section{REFERENCES}

Banton, M. (1964). The Policeman in the Community. New York.

Bayley, D.H.(1990). Patterns of Policing: A comparative Intenational Analysis. New Brunswick: Rutgers University Press.

Вујанић, М., Гортан-Премик, Д., Дешћ, М., Драгићевић, Р., Николић, М., Ного, Љ., Павковић, В., Рамић, Н., Стијовић, Р., Тешић, М. \& Фекет, Е. (2007). Речник српског језика. Нови Сад.

Ђоровић, И. (2011). Структура радног времена униформисаних припадника полиције са освртом на ППУ Крагујевац. Безбедност, 54 (2), 219-237.

Кешетовић, Ж. (2004). Однос полиције и јавности. Безбедност 47 (5-6), 519-548.

Милетић, С. (2009). Коментар Закона о полицији. Београд.

Милидраговић, Д. (2016). Организација и делатност полиције опште надлежности у превенцији и репресији криминалитета, Докторска дисертација, Правни факултет у Универзутета у Крагујевцу.

Милић, Н.(2012). Мапирање криминала у функцији проблемски оријентисаног рада полиције, Наука-Безбедност-Полиција 17 (1), 123-140.

Плачков, Р. (2008). Проблеми рада полиције на локалном подручју, Наука-Безбедност-Полиција 13 (3), 129-147.

Champion, D. (2003). Policing in the Community. Sarajevo.

Закона о полицији, Службени гласник РС, бр. 6/2016, 24/2018 и 87/2018.

Закон о прекршајима, Службени гласник РС, бр. 65/2013, 13/2016 и 98/2016-одлука Уставног суда.

Законик о кривичном поступку, Службени гласник PC, бр. 72/2011, 101/2011, 121/2012, 32/2013, 45/2013, 55/2014.

Закон о извршењу кривичних санкција, Службени гласник РС, бр. 55/2014.

Закону о парничном поступку и Службени гласник РС, бр. 72/2011, 49/2013-одлука УС, 74/2013-одлука УС, 55/2014 и 87/2018.

Закону о општем управном поступку, Службени гласник РС, бр. 18/2016.

https://sudpol-fbih.pravosudje.ba/, доступно 25.01.2019. године.

https://ossud-brckodistriktbih.pravosudje.ba/vstv/faces/kategorijevijesti.jsp?ins=90

\&modul=7254\&kat=7285\&kolona=7269, доступно 25.01.2019. године.

https://sudpol-rs.pravosudje.ba/, доступно 25.01.2019. године. 


\section{ПОСТУПАҢЕ ПОЛИЦИЈЕ ПО НАРЕДБАМА И ЗАМОЛНИЦАМА НАДЛЕЖНИХ СУБЈЕКАТА}

Прегледни научни рад

\begin{tabular}{|l|l|l|}
\hline DOI 10.7251/ZBK1901011M & COBISS.RS-ID 8272408 & УДК 351.74/.76:343.14/.15 \\
\hline
\end{tabular}

Драган Милидраговић ${ }^{1}$

мУП Републике Србије

Дане Субошић

Криминалистичко-полицијски универзитет, Београд

Ненад Милић

Криминалистичко-полицијски универзитет, Београд

Сажетак: Полиција поред полицијских послова таксативно набројаних у чл. 30, ст. 3 Закона о полицији обавља и друге послове и задатке утврђене законом и подзаконским актом. Један део ових послова односи се на пружање помоћи другим државним органима, пре свега надлежним судовима и тужилаштвима у обављању послова из њиховог делокруга, а састоји се у поступању по њиховим наредбама и замолницама. Да би утврдили колико времена полицијски службеници на безбедносном сектору проводе решавајући наредбе и замолнице у раду су представљени делови из четири истраживања која говоре о ангажовању полиције на овим задацима. Представљени резултати истраживања указују нам да је полиција Републике Србије највише радног времена ангажована на решавању наредби и замолница и на другим пословима који нису у вези са превенцијом и репресијом криминалитета. Оптерећеност полицијских службеника све већим бројем наредби и замолницама, поред представљених резултата истраживања, потврђују и статистички подаци МУП Републике Србије у периоду од 2010. до 2013. године, који су такође представљени у раду. Према статистичким подацима правосудни органи у просеку годишње доставе на поступање преко 101.000 захтева за уручење позива и око 435.000 наредби за довођење лица, као и преко 100.000 захтева за проверу адресе пребивалишта, од којих се 75\% односи на теренску проверу пребивалишта. Проблем утрошка већег дела радног времена полицијских службеника на поступање по наредбама и замолницама присутан је више од десет година у раду полиције на безбедносном сектору. У решавању овог проблема аутори предлажу да се сагледају искуства других држава чије су полиције један део својих послова повериле другим државним органима или сектору приватне безбедности.

Кључне речи: полиција, наредбе, замолнице, статистички подаци, радно време

\footnotetext{
${ }^{1}$ Аутор за кореспонденцију: др Драган Милидраговић, мУП Републике Србије. E-mail: dragan.milidragovic@mup.gov.rs.
} 


\section{УВОДНА РАЗМАТРАњА}

Полиција поред полицијских послова таксативно набројаних у чл. 30, ст. 3 Закона о полицији - 30П ${ }^{2}$ обавља и друге послове и задатке утврђене законом и подзаконским актом. Један део ових послова и задатака полиције односи се на пружање помоћи другим државним органима, надлежним судовима и тужилаштвима (у даљем тексту помоћ овлашћеним органима) у обављању послова из њиховог делокруга.

Помоћ овлашћеним органима треба разликовати од полицијске помоћи у извршењима и поступцима вансудског намирења (у даљем тексту полицијска помоћ). ${ }^{3}$ Полицијска помоћ пружа се извршним органима односно правним и физичким лицима са јавним овлашћењима при извршењу њихових аката и то у случајевима када се основано очекује отпор лица према коме или према чијој имовини се мере извршења примењује.

Основа разлика између ове две врсте помоћи је у времену њеног пружања. Полицијска помоћ пружа се након спроведеног поступка код надлежног органа и то онда када је по правноснажности пресуде донето решење и закључак о извршењу и када је од стране извршних органа покушано извршење. За разлику од полицијске помоћи, помоћ овлашћеним органима пружа се у току поступка.

Правни основ за пружање полицијске помоћи садржан је у чл. 53 30П, док је правни основ за пружање помоћи овлашћеним органима предвићен у чл. 30 , ст. 3 , тач. 12 30П-а.

У ст. 3, чл. 30 ЗОП-а, набројани су полицијски послови, док је у тач. 12 овог члана наведено да се полицијски послови односе и на извршавање других послова и задатака утврђених законом и подзаконским актом донетим на основу овлашћења из закона.

Према мишљењу Слободана Милетића други задаци утврђени законом и подзаконским прописима, представљају полицијске послове ако су као такви одређени тим законима и другим прописима. Ако то није случај, може се закључити да јесу полицијски послови само ако испуњавају иста мерила као и други полицијски послови. Та мерила односе се на: 1)

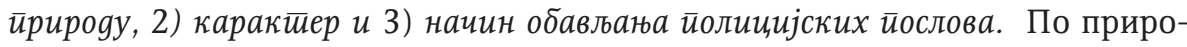
ди и карактеру полицијски послови су претежно безбедносни и оперативно-стручни, при њиховом обављању најчешће се примењују и (особена) полицијска овлашћења. По начину обављања одликује их конкретност и непосредност у поступању, пружање безбедносне заштите на месту догађаја (полицијска интервенција на лицу места). За разлику од полицијских послова, циљ обављања других унутрашњих послова није заштита безбедности, они су само у функцији јавне безбедности. По природи и карактеру, други унутрашњи послови су претежно управни и стручни (неуправни) послови

\footnotetext{
${ }^{2}$ Службени іласник PC, бр. 6/2016, 24/2018 и 87/2018. Видети чл. 30 Закона о полицији.

${ }^{3} \mathrm{O}$ начину пружања полицијске помоћи видети у чл. 53-56 Закона о полицији.
} 
управе. По начину обављања не одликује их конкретност и непосредност полицијског поступања, због чега их поред полиције може обављати и неки други орган (Милетић, 2009: 45).

Полицијски послови који се односе на откривање и хапшење учинилаца кривичних дела и прекршаја и других лица за којима се трага и привођење надлежним органима, обезбеђивање доказа, њихова анализа, криминалистичко-форензичко вештачење употребом савремених форензичких метода и евиденција, захтевају примену полицијских овлашћења, као што су саслушање осумњичених, прикупљање обавештења од грађана, надзор над комуникацијама, вештачење и слично.

Према мерилима које наводи С. Милетић послове откривања кривичних дела, можемо сматрати безбедносним и оперативно-стручним и у њиховом извршењу полицијски службеници примењују полицијска овлашћења. У случају трећег мерила, које наводи С. Милетић сматрамо да конкретност и непосредност поступања на лицу места, нису битни критеријуми да би се одређени посао сматрао полицијским послом. Поједина полицијска овлашћења у поступку откривања и расветљавања кривичног дела не примењују се на лицу места, (саслушање осумњиченог, надзор над комуникацијама и слично), исти случај је са поступањем по издатим наредбама и упућеним замолницима. Поступање по овим актима, захтева примену полицијских овлашћења, као што су провера идентитета, довођење, некада и употребу средстава принуде. На основу овог објашњења, можемо констатовати да су полицијски послови, они послови, чије извршење захтева примену полицијских овлашћења и који су у директној или индиректној функцији безбедности.

Прецизније обавезе полиције у поступању по наредбама и замолницама садржане су у Закону о прекршајима - 3П 4 , Законику о кривичном поступку - ЗКП ${ }^{5}$, Закону о извршењу кривичних санкција - ЗОИКС ${ }^{6}$, Закону о парничном поступку - ЗПП ${ }^{7}$ и Закону о општем управном поступку -3УП. ${ }^{8}$

У стручној литератури као и у позитивним прописима није одређен појам наредбе и замолнице. У Речнику српског језика наредба је дефинисана као: а) правни акт који доноси орган власти одређујући обавезе физичких и правних лица над којима су надлежни, б) уопште захтев онога ко има власт или моћ, војну силу или слично, којом се одређује нешто као обавеза, заповест (Вујанић et al., 2007: 788).

Узимајући у обзир ова значења, наредбу можемо дефинисати као правни акт органа власти, којим они наређују извршење одређених радњи

${ }^{4}$ Службени іласник PC, бр. 65/2013, 13/2016 и 98/2016-одлука Уставног суда.

${ }^{5}$ Службени іласник РС, бр. 72/2011, 101/2011, 121/2012, 32/2013, 45/2013, 55/2014 .

${ }^{6}$ Службени гласник РС, бр. 55/2014.

${ }^{7}$ Службени гласник РС, бр. 72/2011, 49/2013-одлука УС, 74/2013-одлука УС, 55/2014 и 87/2018.

${ }^{8}$ Службени ілласник РС, бр. 18/2016. 
надлежним субјектима ради окончања њиховог поступка. Надлежна тужилаштва и судови наредбу могу издати ради довођења окривљеног у циљу његовог саслушања, уколико се уредно позвани окривљени не одазове после уредно урученог позива, а свој изостанак не оправда или уколико се није могло извршити уредно уручење позива за саслушање. Основ за поступање по наредбама надлежних тужилаштава и судова за довођење окривљеног ради саслушања, представљају законска решења у ЗКП-у9 вођење окрвиљеног у прекршајни суд представљају решења садржана у 3П. ${ }^{10}$ Поред наредби за довођење лица у току поступка, надлежни судови издају наредбе и за довођење кажњених ${ }^{11}$ или осуђених лица. ${ }^{12}$

У речнику српског језика, замолница се дефинише као писмена молба једног суда другом суду, да му укаже правну или техничку помоћ (Вујанић et al., 2007: 403). Полазећи од овог одређења, замолницу можемо дефинисати као молбу државног органа упућену другом државном органу ради пружања правне или техничке помоћи, неопходне за покретање или окончање одређеног поступка. Замолнице државних органа упућене полицији најчешће се односе на уручење разних решења, пресуда, позива, провера адреса пребивалишта и слично.

У полицијској пракси наредбе и замолнице извршава полиција опште надлежности и њихово извршавање представља једну врсту споредних односно услужних послова. Број наредби и замолница који се данас достављају полицији на поступање постаје све већи и њихова реализација захтева све већи утрошак одређених ресурса и времена.

\section{РЕЗУЛТАТИ ИСТРАЖИВАҢА О ПОСТУПАҢУ ПОЛИЦИЈЕ ПО НАРЕДБАМА И ЗАМОЛНИЦАМА}

У овом делу рада представљени су делови из три истраживања о организацији и раду полиције у превенцији и репресији криминалитета, два истраживања извршена су путем анкетног листа, једно истраживање извршено је путем интервјуа. Такође у овом делу рада представљен је део истраживања Ивана Ђоровића, као и запажања појединих аутора која указују на оптерећеност полиције наредбама, замолницама и другим администаративним пословима.

У 2011. години ради сагледавања ангажовања полиције на безбедносном сектору у обављању полицијских послова реализовано је истраживање на подручју две највеће полицијске управе у МУП-у Републике Србије, и то

\footnotetext{
${ }^{9}$ Видети чл. 195 и 196 ЗКП.

${ }^{10}$ Видети чл. 188 и 189 ЗП.

${ }^{11}$ Видети више у чл. 217-220 ЗОИКС.

${ }^{12}$ Видети више у чл. 53-58 ЗОИКС.
} 
на подручју Полицијске управе за град Београд и Полицијске управе Нови Сад.

У анкети је учествовало 415 полицијских службеника полиције опште надлежности, 260 полицијских службеника који раде на територији за коју је надлежна Полицијска управа за град Београд (62\% испитаника) и 155 полицијских службеника који раде на територији за коју је надлежна Полицијска управа у Новом Саду (38\% испитаника).

Путем анкете испитаницима је постављено 20 питања, која су се односила на поступање полиције по наредбама и замолницама надлежних субјеката, превентивни и репресивни рад полиције на безбедносном сектору и мотивацију полицијских службеника.

Истраживањем су обухваћене следеће полицијске испоставе у Полицијској управи Нови Сад: Стари град, Детелинара, Клиса, Петроварадин, Лиман и Футог, и три полицијске станице у Полицијској управи за град Београд: Земун, Стари град и Нови Београд. ${ }^{13}$

Према радном искуству полицијски службеници који су анкетирани сврстани су у четири групе, прва група од 0 до 3 године радног искуства, друга група од 3 до 5 година радног искуства, од 5 до 10 година и преко 10 година радног искуства. Од 415 анкетираних полицијских службеника највише је оних преко 10 година радног искуства, који од укупног узорка чине $38,8 \%$, затим полицијских службеника са радним искуством од 5 до 10 година, са уделом од 30,8\%, полицијских службеника од 3 до 5 година радног искуства, са уделом од 13,5 \% и полцијских службеника од 0 до 3 године радног искуства, са уделом од $16.9 \%$ (Табела 1).

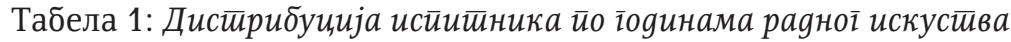

\begin{tabular}{|c|c|c|}
\hline 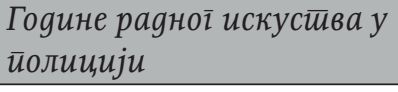 & Број истиитианика & 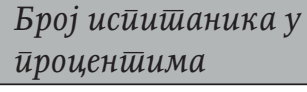 \\
\hline Од 0 до 3 године & 70 & $16.9 \%$ \\
\hline Од 3 до 5 година & 56 & $13.5 \%$ \\
\hline Од 5 до 10 година & 128 & $30.8 \%$ \\
\hline Преко 10 година & 161 & $38.8 \%$ \\
\hline Укупно & 415 & $100 \%$ \\
\hline
\end{tabular}

Анкетирањем су обухваћени полицијски службеници који су у полицијским испоставама распоређени на радна места: полицајца, вође сектора, заменика вође сектора шефа (вођа) смене и помоћника шефа (вође) смене. У структури анкетираних полицијских службеника у полицијским испоста-

${ }^{13}$ О овом истраживању видети више (Милидраговић, 2016: 42-69). 
вама највећи број је полицајца 73.3\% или 304 полицајца, шефова (вођа) смена и помоћника шефова (вођа) смене 13.5\% или 56 анкетираних и $13.3 \%$ односно 55 анкетираних вођа и заменика вођа сектора (Табела 2).

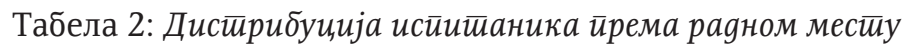

\begin{tabular}{|c|c|c|}
\hline $\begin{array}{l}\text { Раяно местио у йолицијској } \\
\text { исиосииави }\end{array}$ & Број исиичианика & $\begin{array}{l}\text { Резулишай у } \\
\text { ироиенииима }\end{array}$ \\
\hline Полицајац & 304 & $73.3 \%$ \\
\hline $\begin{array}{l}\text { Вођа сектора и заменик вође } \\
\text { сектора }\end{array}$ & 55 & $13.3 \%$ \\
\hline $\begin{array}{l}\text { Вођа (шеф) смене и помоћник } \\
\text { вође (шефа) смене }\end{array}$ & 56 & $13.5 \%$ \\
\hline Укупно & 415 & $100 \%$ \\
\hline
\end{tabular}

Већина испитаника односно 70\% има преко пет година радног искуства у полицији. Чињеница да више од две трећине испитаника има значајно радно искуство у полицији (5 и више година) даје посебну вредност добијеним резултатима истраживања (31\% испитаника, има од 5 до 10 година и $39 \%$ испитаника, има преко 10 година радног стажа).

Од укупно 20 питања из анкете, испитаницима су о поступању полиције по издатим наредбама и упућеним замолницама постављена два питања. Пре ова два питања, испитаницима је понуђена могућност да се сами изјасне, уписивањем бројева од 1 до 5 испред понуђених полицијских послова (обезбеђење јавних скупова; сузбијање криминалитета - откривање и расветљавање кривичних дела и проналажење учинилаца и лица за којима се трага; одржавање јавног реда и мира; решавање наредби и замолница и превентивни обиласци безбедносног сектора) о полицијском послу који им у току радне смене одузима највише времена. Број 1 означавао је посао који захтева највише радног ангажовања, а број 5 полицијски посао који захтева најмање радног ангажовања у току једне радне смене.

Од свих наведених послова који се свакодневно обављају, 49,9\% испитаника изјаснило се да су највише времена у току радне смене ангажовани на поступању по издатим наредбама и упућеним замолницама. Овак-

14 вом дистрибуцијом снага и средстава, полиција све мање ресурса ангажује на приоритетне полицијске послове, пре свега на превенцију и репресију криминалитета и одржавање јавног реда и мира. Све већи број наредби и замолница надлежних судова и других државних органа, полицију ставља у положај курирске службе која своје снаге и средства и ресурсе ангажује на извршавању ових послова (Слика 1). 


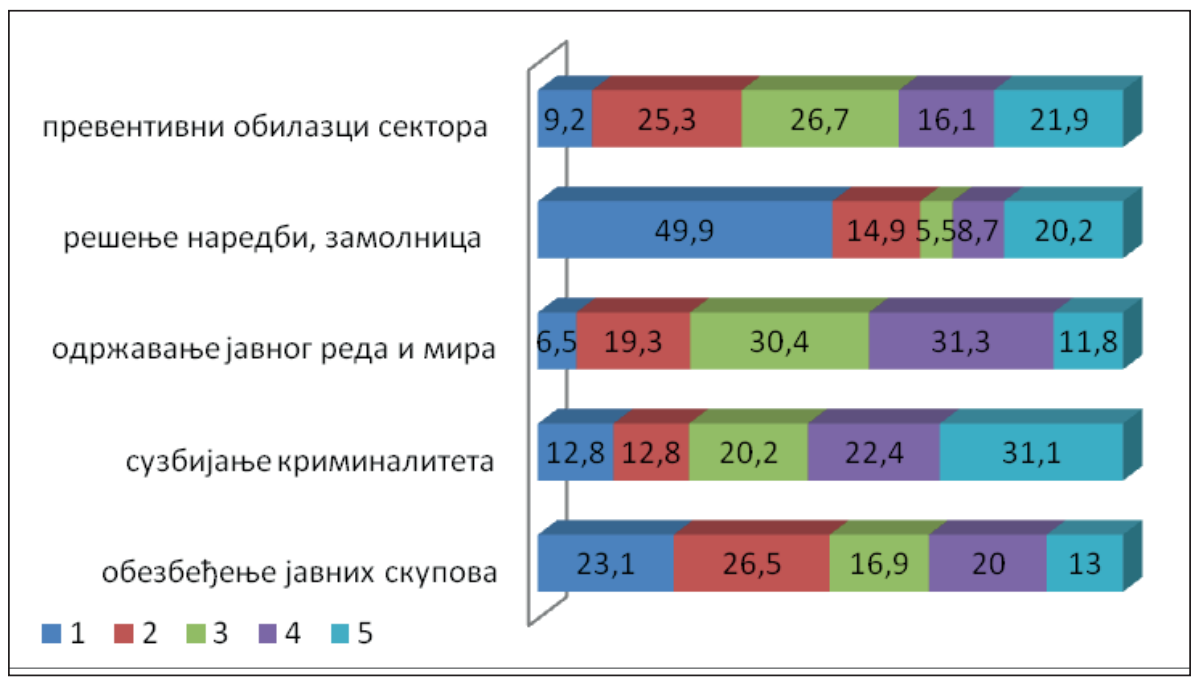

Слика 1: Дистрибуција радног времена полицијских службеника

Често се запоставља чињеница да је мањак ресурса подједнако лош за полицијску организацију као и њихово нерационално коришћење. С тим у вези, оптимизација ангажовања расположивих ресурса подразумева и анализу садржаја рада полицијских службеника у структури њиховог радног времена. На пример, значајан део радног времена полицијски службеници проводе у обављању послова који немају везе са криминалитетом и одржавањем јавног реда и мира. Послови попут вршења безбедносних провера за пријем у радни однос, провера за набавку ватреног оружја, поступања по замолницама других државних органа (на пример, утврђивање адресе пребивалишта) за последицу имају да се послови превентивног деловања (на пример, обиласци угоститељских објеката у којима долази до учесталог вршења кривичних дела и прекршаја, стварање и унапређење партнерских односа са члановима заједнице и друго) или расветљавања кривичних дела, стављају у други план. ${ }^{14}$

У намери да сагледамо колики се део радног времена полицијског службеника утроши на обављање оваквих послова и задатака, у спроведеном истраживању, питали смо полицијске службенике колико времена у току службе (смене) проводе решавајући наредбе, замолнице, вршећи уручења пресуда и позива, провере адреса и решавајући друге захтеве судова. Највећи број њих (46\%) одговорио је да више од 3 сата свог радног времена утроши на обављање ових послова. Такође, петина испитаника (20\%) ове послове обавља од 1 до 2 сата током своје смене, док 22\% испитаника, на ове послове утроши

\footnotetext{
${ }^{14}$ Реализована истраживања у САД показала су да у укупном обиму полицијског посла, тек око $20 \%$ до 30\% обухватају послови везани за сузбијање криминалитета и принудно спровођење закона. Полицајци 70\%-80\% радног времена троше на тзв. „социјално услужни рад“ полиције, а не на активности у вези са криминалитетом (Banton, 1964: 6-7).
} 
од 2 до 3 сата свог радног времена. Скоро сваки десети испитаник на ове послове утроши до 1 сата свог радног времена (Табела 3).

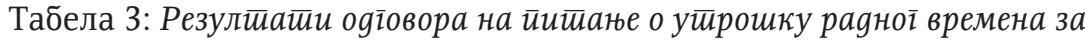
иостиуйање йо нареgбама и замолнии,ама

\begin{tabular}{|c|c|c|}
\hline Понуђени ояі̄овори & Број исииитианика & Резулйай у иррои,енйима \\
\hline До 1 час & 50 & $12 \%$ \\
\hline Од 1 до 2 часа & 82 & $20 \%$ \\
\hline Од 2 до 3 часа & 91 & $22 \%$ \\
\hline Преко 3 часа & 192 & $46 \%$ \\
\hline Укупно & 415 & $100 \%$ \\
\hline
\end{tabular}

Имајући у виду претходно наведено, можемо закључити да обављање оваквих послова у значајној мери оптерећује полицијске службенике у урбаним срединама, и да се, с тим у вези, мора изнаћи неки начин како ови послови не би угрожавали редовно функционисање полицијске организације и стање безбедности на одређеној територији. Овај став потврђују и резултати одговора на питање о надлежности за поступање по наредбама и замолницама. Убедљиво највећи број полицијских службеника (76\% анкетираних) сматра да полиција не треба да обавља ове послове (поступање по наредбама и заполницама), (Табела 4).

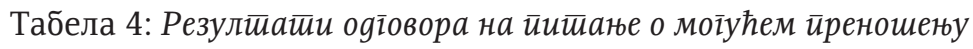

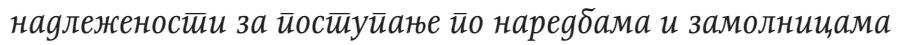

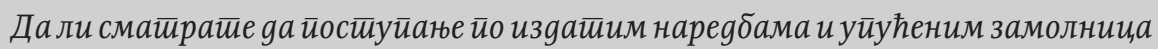

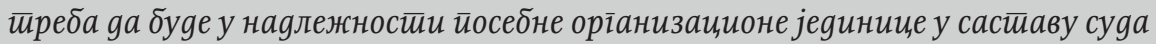
(нирр. суgске иолииије и слично)?

\begin{tabular}{|c|c|c|}
\hline Понуђени оgі̄овори & 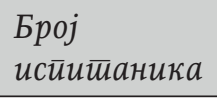 & $\begin{array}{l}\text { Резулйай } y \\
\bar{u} р о и, н \overline{и и м м ~}\end{array}$ \\
\hline Полиција не треба да обавља ове послове & 316 & $76 \%$ \\
\hline Полиција треба да обавља ове послове & 54 & $13 \%$ \\
\hline Немам став & 45 & $11 \%$ \\
\hline Укупно & 415 & $100 \%$ \\
\hline
\end{tabular}

Треба тежити томе да се за део послова који тренутно обављају полицијски службеници (провера адреса становања, уручивање судских пресуда и решења, асистенције и друго) формирају неке друге службе које се налазе 
у оквиру правосудних органа (нпр. судска полиција), или пак да се размисли о могућностима ангажовања помоћне полиције за обављање ових послова у оним полицијским испотавама/станицама у којима ови послови угрожавају нормално функционисање полицијске организације.

Анализирајући проблеме рада полиције на локалном подручју 2008. године, Радослав Плачков закључио је да полицијски службеници већи део свог времена проводе обављајући провере за пријем у радни однос, за набавку ватреног оружја, асистенције, замолнице других државних органа које се најчешће односе на утврђивање адресе становања, поступање по наредбама органа за прекрашје о довођењу лица због неплаћања мандатних казни, који на једном градском сектору у току године има по више хиљада и слично (Плачков, 2008: 136-137).

До истог закључка дошао је професор Желимир Кешетовић 2004. године. Професор Ж. Кешетовић анализирајући рад полиције закључио је да све већи број обавеза који се поставља пред полицијске службенике (вође безбедносних сектора и полицајце на безбедносном сектору) отежава им обављање основног задатка - спречавање и сузбијање криминалитета. На основу анализе послова које обављају, професор је закључио да полиција $60 \%$ до 80\% радног времена проведе у обављању послова који немају везе са криминалитетом (Кешетовић, 2004: 526).

На основу истраживања које је спровео анализирајући начин утрошка радног времена полицијских службеника у полицијској испостави у седишту Полицијске управе у Крагујевцу, Иван Ђоровић закључује да би се на овај начин могло „ослободити“ 30\% радног времена, које би могло бити искоришћено за друге намене, попут већег ангажовања полиције на садржајима концепта рада полиције у заједници (Ђоровић, 2011: 232).

У периоду од марта до јуна 2014. године обављен је интервју са руководиоцима организационих јединица задужених за организацију и праћење рада полиције у заједници. Такође, у истом периоду путем анкетног листа извршено је испитивање у свих 27 полицијских управа о организацији и раду полиције опште надлежности у превенцији и репресији криминалитета, као и о поједниним факторима који утучу на њен рад. ${ }^{15}$

Интервју је обављен са руководиоцима Одсека за организацију, превенцију, оспособљавање и рад полиције у заједници у Новом Саду, Крагујевцу, Нишу у одељењима полиције подручних полицијских управа, затим са начелником Одељења за превенцију и рад полиције у заједници, у Полицијској управи за град Београд и начелником Одељења за превенцију и рад полиције у заједници у Управи полиције у седишту Дирекције полиције.

Испитаницима је постављено укупно 15 питања о заступљености рада полиције у заједници у полицији опште надлежности, о постигнутим ефектима и проблемима у раду. Сви испитаници су одговарајући на питање о заступљености превенције на безбедносном сектору истакли да превентивни

${ }^{15}$ Видети више (Милидраговић, 2016). 
рад није заступљен на првом месту због све већег обима послова који се односе на наредбе и замолнице, затим и због малог броја извршилаца, односно полицајаца у полицијским испоставама, неадекватне организационе структуре полиције, непостојања знања о превенцији и раду полиције и фокуса на решавању дневних, односно краткорочних проблема.

Путем анкетног листа укупно је испитано 359 полицијских службеника. У истраживању су учествовали руководиоци у Управи/Одељењу полиције (начелник, заменик начелника, руководилац одсека) руководиоци у ПС/ПИ (командир, заменик и помоћник командира) и официри у Управи/Одељењу полиције.

Више од половине, 188 од 359 (52,4\%), испитаних полицијских службеника били су руководиоци у полицијској станици/испостави (командир, заменик и помоћник командира), најмање $33(9,2 \%)$ испитаника су руководиоци у Управи/Одељењу полиције (начелник, заменик начелника, руководилац одсека). Официра у Управи/Одељењу полиције било је 138 (38,4\%).

Одговарајући на питање о заступљености превенције у свакодневном раду полиције, највећи број испитаника 310/359 изјаснио се да превентивне активности нису заступљене у свакодневном раду полиције. Овим испитаницима понуђена је могућност да се изјасне на факторе који према њиховом мишљењу утичу на незаступљеност превенције у свакодневном раду полиције. Највећи број испитаника, 285/310 односно 79,4\%, сматра да превентивне активности нису заступљене у свакодневном раду полиције због преоптерећености полиције пословима као што су уручење замолница и решавање наредби надлежних субјеката.

На основу ових резултата истраживања и запажања наведених аутора, поставља се питање да ли оваква организација рада полиције може са успехом испунити очекивања грађана који је кроз порезе финансирају и чијим интересима треба да служи. Да би контролисала криминалитет она мора да уђе у претпоље криминалитета како би сагледала и деловала на узроке и услове који воде његовом настанку. Међутим, како се ти узроци и услови, по правилу, налазе изван домашаја полицијског деловања, ту се и јавља неопходност мобилизације других субјеката у друштву како би се заједнички супротставили криминалитету. Оног тренутка када се схватило да се полиција сама не може супротставити криминалитету, а нарочито неким чиниоцима који утичу на квалитет живота грађана, постало је јасно да партнерство са заједницом, али и другим субјектима постаје важан елеменат вршења полицијске функције. ${ }^{16}$

${ }^{16}$ Рад полиције у заједници ставља нагласак на превенцију као примарни задатак полиције. Он се заснива на стратегији комуникације, сарадњи и ослањању полиције на грађане уз истовремено максимално ограничавање примене силе и њено замењивање акцијом уверавања и партнерства (Bayley, 1990: 85).

Концепт полиције у заједници подразумева удруживање грађана и полиције у борби против криминалитета, односно обављање полицијских послова уз партнерство полиције и заједнице у циљу смањења криминалитета и повећања безбедности у локалној заједници (Champion, 2003: 2). 
Ако се пође од тога да многи проблеми који захтевају полицијско поступање настају и манифестују се у локалној заједници, онда је и успостављање и одржавање партнерских односа са заједницом, предуслов ефикасног рада полицијске организације. Управо због тога и треба створити организационе претпоставке у раду полиције које ће то и омогућити. Због тога се треба вратити имплементацији концепата рада полиције у заједници и проблемски оријентисаног рада ${ }^{17}$, који су код нас прилично запостављени, а чији је значај у савременој полицијској пракси одавно потврђен.

Представљени резултати истраживања говоре нам да је наша полиција највише радно ангажована на "курирским" и другим пословима који нису у вези са превенцијом и репресијом криминалитета. Овакава организација рада полиције, захтева промене у организацији рада, успоставање партнерских односа са заједницом и примену концепта рада полиције у заједници.

\section{СТАТИСТИЧКИ ПОКАЗАТЕЉИ О ПОСТУПАЬУ ПОЛИЦИЈЕ ПО НАРЕДБАМА И ЗАМОЛНИЦАМА}

Оптерећеност полицијских службеника све већим бројем издатих наредби и упућених замолницама, поред представљених резултата истраживања, потврђују и статистички подаци МУП-а Републике Србије у периоду од 2010. до 2013. године.

Према евиденцијама МУП-а Републике Србије од 2010. године забележено је повећања броја захтева надлежних судова и тужилаштава ради пружања њима потребне помоћи у кривичном и у прекршајном поступку. Број захтева за уручење позива у прекршајном поступку у 2013. години у односу на 2010. годину, повећан је за $42 \%$, док је број захтева за уручење позива у кривичном поступку у истом периоду, повећан за 55,2\%.

Полицијски службеници су у периоду од 2010. до 2013. године, просечно месечно уручивали 3.705 позива прекршајних судова и 4.319 позива тужилаштва и судова надлежних за вођење кривичног поступка. У наведеном периоду од стране полиције опште надлежности, реализовано је преко 80\% упућених позива од стране прекршајних судова и око 95\% упућених позива од стране тужилаштва и судова надлежних за вођење кривичног поступка. Највише захтева за уручење позива у посматраном периоду, евидентирано је на подручју Полицијске управе за град Београд (просечно месечно запримљено око 1.700 позива), а најмање на подручју Полицијске управе у Пријепољу (месечно по 32 позива).

17 Инциденти који су предмет полицијског деловања (интервенције) само су симптоми (последице) проблема и наставиће да се манифестују све док постоје узроци и услови који их продукују. Због тога се, у оквиру проблемски оријентисаног приступа, полицијско поступање не завршава „решавањем“ инцидентних ситуација (нпр. подношење кривичне или прекршајне пријаве против извршиоца), већ се наставља с циљем идентификовања скривених узрока и услова који су довели до њихове појаве (Милић, 2012: 125). 
Полиција је у наведеном периоду, просечно месечно запримала 27.909 наредби издатих од прекршајних судова. Од овог броја запримљених наредби, полиција је месечно реализовала око 21.376 наредби. За разлику од овог броја, број запримљених наредби од стране судова надлежних за вођење кривичног поступка био је много мањи и он је просечно месечно износио 8.376 наредби. Полицијски службеници су од овог броја запримљених наредби у току месеца, просечно извршавали 6.994 наредбе. Полиција Републике Србије је у посматраном периоду, просечно у току месеца, запримила 8.334 захтева за проверу адресе пребивалишта, од наведеног броја полицијски службеници су просечно месечно реализовали 6.780 захтева.

Припадници полиције опште надлежности поред захтева надлежних судова и других државних органа за поступање по наредбама и замолницама, поступају и по захтевима других организационих јединица полиције (саобраћајне полиције, криминалистичке полиције и других), који се односе на уручење решења о казни, уручење саопштења о изреченим заштитним мерама и мерама безбедности, поступање по захтевима за одузимање пасоша, обављање безбедносних провера ради пријема у држављанство, радни однос и у вези поднетих захтева за држање и ношење оружја.

Припадници полиције опште надлежности у посматраном периоду, месечно су извршавали 2.542 безбедносне провере (пријем у држављанство, пријем у радни однос у МУП-у и провере у вези оружја) и просечно су у току месеца извршили 258 налога за одузимање пасоша.

Поступање по захтевима надлежних судова представља значајан и по свему судећи специфичан део послова из делокруга рада полиције опште надлежности, јер без уредне доставе код уручења позива или без проналажења и довођења окривљеног није могуће окончати покренути кривични поступак. На основу садржине захтева (уручење позива, пресуде, извршавање наредбе и друго), може се закључити да је полиција опште надлежности била ангажована у свим фазама прекршајног и кривичног поступка, о чему нам говори чињеница да су правосудни органи у просеку годишње достављали на поступање преко 101.000 захтева за уручење позива и око 435.000 наредби за довођење лица, као и преко 100.000 захтева за проверу адресе пребивалишта, од којих се 75\% односи на теренску проверу пребивалишта.

Велики број захтева полицији опште надлежности упућују и друге организационе јединице МУП-а. Полицијски службеници полиције опште надлежности годишње, просечно у 3.925 случајева поступају по налогу за одузимање пасоша и изврше око 30.000 безбедносних провера ради пријема у држављанство, радни однос и у вези оружја. На захтев саобраћајне полиције, полицијски службеници опште надлежности изврше уручење око 71.000 решења и скоро 30.000 саопштења о изреченим заштитним мерама и мерама безбедности.

Представљени резултати истраживања и статистички подаци МУП-а Републике Србије о поступању по издатим наредбама и замолницама указују 
нам на дневну оптерећеност полицијских службеника овим пословима, услед чега се послови превенције и репресије криминалитета стављају у други план.

\section{ЗАКљУЧАК}

Полиција опште надлежности данас као и годинама уназад велики део расположивог радног времена, снага и средстава, издваја за поступање и рад по захтевима надлежних тужилаштава, судова, других државних органа и организационих јединица МУП-а.

Поред великог броја достављених наредби и замолница у пракси су уочени проблеми, како нормативне, тако и практичне природе, који отежавају рад полицијских службеника. Процедура поступања по издатим наредбама и упућеним замолницама, указује на преобимну администрацију, почевши од пријема захтева, затим евидентирања у полицијске евиденције, проверу оправданости и тачности података, организивање рада, поступање по захтевима на безбедносном сектору, сачињавање извештаја о поступању, одговоре на поднете захтеве, контролу рада и друго.

Поступања полицијских службеника по издатим наредбама и упућеним замолницама нису прописана у 3ОП-у или било ком подзаконском акту. У ЗП, ЗКП, ЗУП и ЗОИКС, наведена је само обавеза полиције да пружи потребну помоћ ради обављања послова из надележности тужилаштава, судова и других.

До ступања на правну снагу актуелног 3ОП-а у пракси је посебно био изражен проблем фиктивно пријављених лица на одређеним адресама, као и проблем проналаска ових лица, јер они на разне начине настоје да избегну или отежају извршење наредби и пријем писмена (позива, решења и слично), због чега полиција више пута поступа за исто лице. ${ }^{18}$

У пракси је забележено да надлежни судови доставе територијално надлежној полицијској испостави велики број наредби и замолница са одређеним роком за реализацију, због чега се понекад ангажују додатне снаге и средства у исто време, само за ове послове.

Поред наведених у пракси су присутни и следећи проблеми: правосудни органи уз захтев не достављају податак да је покушано уручење позива преко надлежних курирских служби; у захтевима за уручење позива наводи се само и име и презиме лица без других података, што отежава његово проналажење; ЗП је омогућио доведеном лицу у суд, да плати казну у више рата и у случају да лице уредно не уплаћује рате, суд издаје поново

18 Забележно да лица за која је издат налог за довођење од стране надлежног суда, од адвоката или на други начин сазнају термин одржавања главног претреса, па уколико им није у интересу да се појаве на суђењу, тог дана излазе из куће и одлазе изван града или код лекара. Новим 3ОП, полицији је дата могућност да распише потрагу за лицем за којим је прекршајни суд издао општу наредбу за довођење (члан 59 став 4 тачка 2 3ОП). 
наредбу за његово довођење, тако да су се нека лица више пута доводила; радно време поступајућих судија је искључиво у преподневним сатима, што некада отежава проналазак лица; у појединим полицијским управама проблем представља и удаљеност месно надлежних судова и слично. ${ }^{19}$

У решавању ових проблема, требало би предузети нормативне и практичне механизме. У 30П-у и подзаконским актима требало би прецизно уредити обавезу и начин поступања полицијских службеника по издатим наредбама и упућеним замолницама. У склопу практичних мера требало би размотрити могућност да се у сарадњи са органима правосуђа уведе електронски инфомациони систем вођења разних евиденција.

На крају, треба сагледати и искуства других земаља чије су полиције један део својих послова повериле другим државним органима или сектору приватне безбедности.

У Републици Српској, Федерацији Босне и Херцеговине и на подручју Брчко дистрикта, Законом о судској полицији основана је судска полиција. ${ }^{20}$

Судска полиција у Републици Српској надлежна је да помаже у раду Врховном суду, Вишем привредном суду, окружним судовима, основним судовима и окружним привредним судовима. Судска полиција Републике Српске у оквиру својих надлежности обавља послове који се односе на осигурање информација; принудно довођење сведока и вештака; принудно довођење и спровођење осумњичених, оптужених и осуђених лица; спровођење осуђених лица у установу за извршење кривичних санкција; спровођење извршења судских одлука; обезбеђује судске и тужилачке зграде; обезбеђује судије и друге раднике суда; одржава ред у судници и другим судским просторијама за време и у току суђења.

Полиција у Републици Србији поред поступања по издатим наредбама и упућеним замолницама надлежних тужилаштава и судова, обавља и друге послове који су на подручју БиХ у надлежности судске полиције, као што су обезбеђење лица у суду за време саслушања од стране истражног судије које је доведено након истека задржавања, превожење лица којима је одређен притвор од стране истражног судије до казнено поправне установе где се спроводи мера притвора, превожење лица пронађених по расписаним потрагама до надлежног суда који је расписао потрагу. ${ }^{21}$

\footnotetext{
${ }^{19}$ Овај проблем уследио је након реформе правосуђа у 2010. години, када је успостављена нова мрежа судова.

${ }^{20} \mathrm{O}$ организацији и делатности судских полиција у Босни и Херцеговини, видети више: https://sudpol-fbih.pravosudje.ba/,

${ }^{21}$ На пример, уколико лице по расписаној потрази од Вишег суда у Лесковцу пронађу полицијски службеници у Суботици, они су у обавези и да изврше довођење лица до просторија суда у Лесковцу. У случају када би била основана судска полиција у Републици Србији, пронађено лице по потрази предало би се најближој организационој јединици судске полиције, која би извршила довођење лица до суда у Лесковцу.
} 
Оснивањем судске полиције на подручју Републике Србије, полиција опште надлежности била би растерећена једног дела „курирских“ послова. Радно време и ресурси који су трошени на извршавање послова по захтеву тужилаштва и суда, усмерили би се на примарне полицијске послове, превенцију и репресију криминалитета, што би се одразило на безбедност грађана и њихове имовине.

\section{ЛИТЕРАТУРА}

Banton, M. (1964). The Policeman in the Community. New York.

Bayley, D.H.(1990). Patterns of Policing: A comparative Intenational Analysis. New Brunswick: Rutgers University Press.

Вујанић, М., Гортан-Премик, Д., Дешћ, М., Драгићевић, Р., Николић, М., Ного, Љ., Павковић, В., Рамић, Н., Стијовић, Р., Тешић, М. \& Фекет, Е. (2007). Речник српског језика. Нови Сад.

Ђоровић, И. (2011). Структура радног времена униформисаних припадника полиције са освртом на ППУ Крагујевац. Безбедност, 54 (2), 219-237.

Кешетовић, Ж. (2004). Однос полиције и јавности. Безбедност 47 (5-6), 519-548.

Милетић, С. (2009). Коментар Закона о полицији. Београд.

Милидраговић, Д. (2016). Организација и делатност полиције опште надлежности у превенцији и репресији криминалитета, Докторска дисертација, Правни факултет у Универзутета у Крагујевцу.

Милић, Н.(2012). Мапирање криминала у функцији проблемски оријентисаног рада полиције, Наука-Безбедност-Полиција 17 (1), 123-140.

Плачков, Р. (2008). Проблеми рада полиције на локалном подручју, Наука-Безбедност-Полиција 13 (3), 129-147.

Champion, D. (2003). Policing in the Community. Sarajevo.

Закона о полицији, Службени гласник PC, бр. 6/2016, 24/2018 и 87/2018.

Закон о прекршајима, Службени гласник РС, бр. 65/2013, 13/2016 и 98/2016-одлука Уставног суда.

Законик о кривичном поступку, Службени гласник PC, бр. 72/2011, 101/2011, $121 / 2012,32 / 2013,45 / 2013,55 / 2014$.

Закон о извршењу кривичних санкција, Службени гласник PC, бр. 55/2014.

Закону о парничном поступку и Службени гласник PC, бр. 72/2011, 49/2013-одлука УС, 74/2013-одлука УС, 55/2014 и 87/2018.

Закону о општем управном поступку, Службени гласник PC, бр. 18/2016.

https://sudpol-fbih.pravosudje.ba/, доступно 25.01.2019. године. 
https://ossud-brckodistriktbih.pravosudje.ba/vstv/faces/kategorijevijesti.jsp?ins=90 \&modul=7254\&kat=7285\&kolona=7269, доступно 25.01.2019. године. https://sudpol-rs.pravosudje.ba/, доступно 25.01.2019. године.

Рад примљен: 03. 02. 2019.

Рад прихваћен: 29. 03. 2019. 